TURIZAM

Volume 17, Issue 4

155-165 (2013)

\title{
Impacts of Artificial Reefs and Diving Tourism
}

\author{
Sandra Jakšić*, Igor Stamenković*, Jasmina Đorđević* \\ Received: August 2013 | Accepted: October 2013
}

\begin{abstract}
Coral reefs are currently endangered throughout the world. One of the main activities responsible for this is scuba-diving. Scuba-diving on coral reefs was not problematic in the begging, but due to popularization of the new sport, more and more tourists desired to participate in the activity. Mass tourism, direct contact of the tourists with the coral reefs and unprofessional behavior underwater has a negative effect on the coral reefs. The conflict between nature preservation and economy benefits related to scuba-diving tourism resulted in the creation of artificial reefs, used both to promote marine life and as tourists attractions, thereby taking the pressure off the natural coral reefs. Ships, vehicles and other large structures can be found on the coastal sea floor in North America, Australia, Japan and Europe. The concept of artificial reefs as a scuba-diving attraction was developed in Florida. The main goal was to promote aquaculture, with the popularization of scuba-diving attractions being a secondary effect. The aim of this paper is to determine the effects of artificial reefs on scuba-diving tourism, while taking into account the questionnaire carried out among 18 divers.
\end{abstract}

Key words: artificial reefs; coral reefs; diving tourism; ships to reefs; socio-economic impacts.

\section{Introduction}

Scuba-diving tourism is a main commercial activity in marine regions (Hsuia, Wang, 2OI3; Garrod, Gossling, 2008), and especially in coral reef zones (Hsuia, Wang, 2OI3; Zakai, Chadwick-Furman, 20O2). However, if the tourist activity is not carefully planned, the degradation of the coral reef is inevitable (Hsuia, Wang, 20I3; Jameson et al., I999; Tratalos, Austin, 2OOI; Zakai, Chadwick-Furman, 2002). With this in mind, many different management strategies were developed in order to reduce the negative effects of scuba-diving activities. One of the effective approaches is the development of artificial reefs (Hsuia, Wang, 2OI3). We can identify four current uses of artificial reefs: (I) tourism (2) recreational fishing (3) nature preservation and (4) science.

I. Tourism: a) scuba diving; b) recreational fishing; c) surfing;

2. Recreational fishing: it consists of many different activities throughout the world, with the necessity to determine the exploitation levels of the attractions, in order to avoid overfishing;

\footnotetext{
* University of Novi Sad, Faculty of Sciences, Department of geography, tourism and hotel management, Trg Dositeja Obradovića 3, 21000 Novi Sad, Serbia; Corresponding author: jsandra88@gmail.com
} 
3. Nature preservation: it is divided into three levels: a) the preservation of unspoiled nature; b) the mitigation of existing damage; c) revitalization of the damaged habitats with the aim of creating new ones;

4. Science: it includes technology directed toward efficient construction of artificial reefs, the monitoring of epifauna, and research.

It was formerly considered that scuba-diving does not have a negative effect on coral reefs if it is properly conducted (Nichols, 2OI3; Barker, Roberts, 2004). However, a rise in popularity and availability of scuba-diving brought new problems into perspective, such as the unsustainable use of natural assets and the destructive behavior of divers. The construction of artificial reefs is one way to deal with the problem, providing new colonizable areas for marine life-forms (Nichols, 2OI3; Fadli et al., 2OI2), shelter from predators for small fish (Nichols, 2OI3; Charbonnel, 2002; Rilov, Benayahub, I998; Rilov, Benayuhu, 2002), but also alternative diving destinations, which takes the pressure off the natural reefs (Nichols, 2OI3; Davis, Tisdell, I996; Feary et al., 2OII; Uy et al., 2008). Structure bases of coral reefs can be sunken ships or vehicles, metal constructions, statues and sculptures (Nichols, 2OI3). Scuba-diving is becoming very popular and it is estimated that about 28 million people actively participate in this activity (Edney, 2006; Garrod, Gossling, 2008). Bearing in mind that divers are in constant pursuit of new challenges, wreck diving presents an exciting

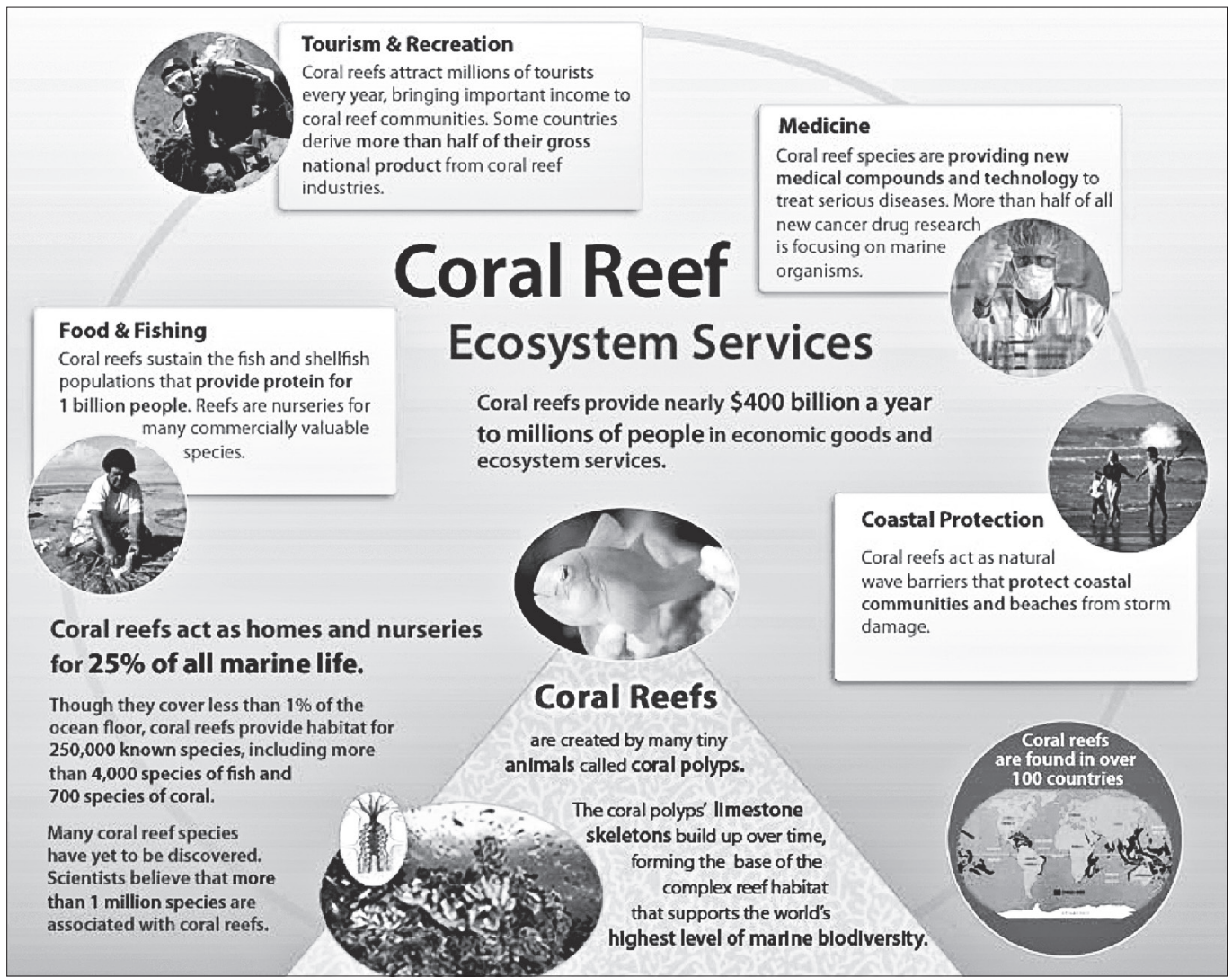

Figure 1. Impacts of Coral Reefs on Ecosystem

Source: http://www.coral.org/files/images/coral-reef-graphic-large.jpg 
alternative. Wreck diving is scuba-diving on artificial reefs that are based on ship wrecks. In many cases, ships are sunken for the sole purpose of creating an artificial reef for wreck diving, and this trend continues to grow. Most of the sunken ships are along the coast of Florida (380), New Jersey (I29), southern California (IOO) and New York (65). The creation of an artificial reef can be very costly, ranging from 46.0oo to 2 million dollars, depending on the size (Pendleton, 2005; Hess et al., 20OI). These expenses represent a direct cash outflow from cities, provinces, countries and non-profit organizations and they are considered good investments, which the local economy will benefit from in the future. For the local government, converting ships into artificial reefs presents an opportunity to enhance the development of tourism, and raise local tax revenue.

\section{Literary review}

The tourism industry makes up 5\% of the global economy (Buckley, 2OII). With the annual growth rate of $6.2 \%$, the annual income of tourism in 2OII. was over I trillion dollars, with the predictions that the number of tourists in 20I2. will reach I billion (Gladstone, et al., 2OI3; UNWTO, 2OI2a). Coastal zones attract the largest number of tourists and the largest growth in the tourism sector is recorded in marine areas (Gladstone, et al., 2OI3; UNEP, 2009). Activities in coastal and marine areas are diverse and include activities on the coast (walking, collecting rarities, animal watching, tours), coastal waters (swimming, surfing, boating), deep waters (yachting, mammal watching, fishing), underwater activities (scuba-diving, shark feeding) as well as many other specialized activities (tourism orientated exploration and adventure tourism) (Gladstone, et al., 2OI3; Hall, 2OOI; Orams, 2007; Wood, 2OIO). Since there is a large number of different factors that contribute to the accelerated degradation of the coral reef environment (Treeck, Schuhmacher, 1999; Salvat, I987; Brown, I900; Wilkinson, I993; Hutchings, I994), and scuba-diving tourism is becoming a major economic factor, measures are being taken in many tropical countries to meet both the tourism demand and the need to protect the environment (Treeck, Schuhmacher, I999; Hawkins, Roberts, I992). Redirecting the underwater activities from natural coral reefs to artificial reefs can be an ideal substitution, using adequate technology to protect the environment while also meeting the demand for scuba-diving (Treeck, Schuhmacher, 1999). Before we investigate the potential of artificial reefs it is necessary to define the term "artificial reef". The European network of researchers defines the artificial reefs as "structures placed on the sea floor with the intention of imitating some of the characteristics of natural reefs" (Pickering, et al., I998; Jensen, I997).

Materials used for this purpose differ from destination to destination. Concrete is the predominantly used material in Europe (Pickering, et al., I998; Bombace et al., I993). Concrete structures in conjunction with steel and fiberglass, are used exclusively in Japan. Rubber is an often suggested material for construction of artificial reefs, and it is used in Australia (Pickering, et al., I998; Brenden et al., I994), Jamaica (Pickering, et al., 1998) and Philippines. In these countries rubber is considered to be non-toxic, widely available and durable. Contrary to this, in Europe many experts consider rubber to be a potential cause of pollution in filtered water. In USA the use of "materials of opportunity" is emphasized (Pickering, et al., I998; Stone et al., I99I). These include various cleansed objects, including oil and gas platforms in the Gulf of Mexico (Pickering, et al., I998; Wilson, Van Sickle, I987; Stanley, Wilson, I990). Japan is the leader in the construction of artificial reefs for purpos- 


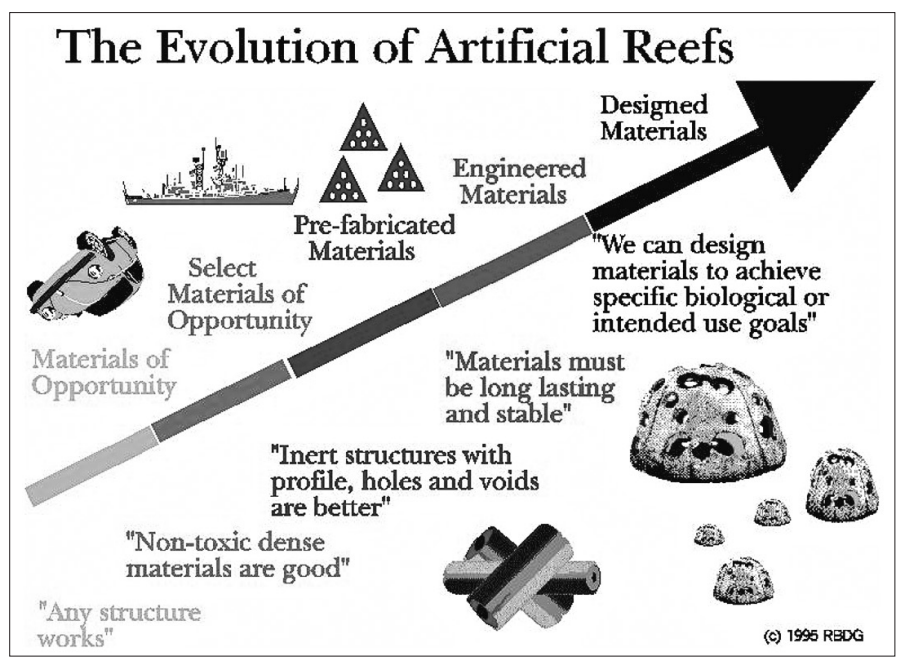

Figure 2. The Evolution of Artificial Reefs

Source: http://www.reefball.org/album/==)\%20Non-Geographic\%20defined\%20Photos/graphics/slides/evolutionofartificialreefs.jpg

es of commercial fishing, while Philippines use artificial reefs for the needs of various fisherman crafts. North America and Australia mostly use artificial reefs for recreational activities such as fishing and scuba-diving. Artificial reefs are still under development in Europe, and include several that are used for research purposes (Sutton, Bushell, 2007; Baine, 2OOI; Jenson, I998; Sayer, Wilding, 2002).

\section{Methods and data}

For the purpose of this paper, besides the literature, it was used a questionnaire that was carried out among I8 divers of different ages, which participated in wreck diving or artificial reef diving at least once. The purpose of the questionnaire was to determine whether the wreck diving and artificial reef diving has a positive or negative effect on the environment in which the activities are practiced. The questionnaire was divided into two parts. The first part explored the wreck diving experience of the interviewed divers, and the second part was related to the socio-demographic characteristics of the respondents.

\section{Possible consequences of scuba-diving on artificial reefs}

Artificial reefs are very susceptible to degradation caused by scuba-diving. Direct contact with the wreck disturbs present life-forms, exposing the metal and accelerating the corrosion process (Edney, 2006; Jewell 2004; Lindemann 1992). Inexperience and inadequate gear are the most common causes of divers coming into contact with the wreck. The degradation of artificial reefs due to scuba-diving has been studied in Australia. The research concluded that the damage caused by improper anchoring and the damage caused by storms, was far greater than the damage caused by divers (Edney, 2006; Harriott, et al., I997). The highest threat to artificial reefs is the damage caused by the anchor, dropped from fishing boats and other sea vessels (Edney, 2006). This kind of physical damage causes accelerat- 
ed corrosion of the artificial reef, up to ten times faster than normal (Edney, 2006; Department of Planning, 1989). The second harmful activity is the collection of artifacts for personal use, as souvenirs or for sale. This practice was present in the 60s and 70s (Edney, 2006; Anderson, I997; Jeffery, I993). Even if the objects were not actually taken, the divers trying to acquire the objects damage the reef or make it more vulnerable to damage from storms and currents, which also leads to faster corrosion (Edney, 2006; Department of Planning, I989; Nutley, 1996). As an addition to the previous text, we will present the scuba-diving codex issued by the British Sub-aqua Club for its members:

I. Do not dive on a designated wreck site without a license. Protected wrecks are indicated on Admiralty charts and marked by buoys, or warning notices on the shore nearby

2. Military wrecks should not be disturbed or items removed from them. This includes the debris field. The debris field is the trail of wreckage that comes away from the main body of the wreck during the sinking process. This trail can consist of parts of the ship, the cargo and the personal possessions of the crew.

3. Do not lift anything that may be of archaeological importance.

4. If you do discover what might be a historic wreck do not talk about it, but contact the Receiver of Wreck, who will advise you about your next steps. If your find is important you may apply for it to be designated a protected wreck site. You can then build up a well-qualified team with the right qualifications to investigate your site with the assistance

5. If you do lift any material from the sea-bed, it is a legal requirement to report it to the Receiver of Wreck as soon as reasonably possible, even if you own the wreck that the material has come from.

6. Avoid the temptation to take souvenirs. Go wreck diving to enjoy the scenery and life, or get involved in projects. If you must take something, try photographs or measurements, and records of marine life.

7. Know and understand wreck law. If you remove material from wreck, which you then sell for profit, you are diving for reward, which is outside the scope of sport diving and you must conduct your dives in strict accordance with HSE regulations. A sound knowledge of wreck law will prevent you breaking the law, perhaps even ending up with a criminal record where no crime was intended (https://www.bsac.com/default. asp)

\section{Socio-economic effects of the artificial reefs on the tourism industry}

The researchers who studied the economic effects of artificial reef construction, support the hypothesis that submerging artificial structures near the coral reefs can mitigate the damage caused by human interference, while at the same time providing the means for the development of scuba-diving centers that contribute to the local economy (US Department of Commerce, 2OI2; Leeworthy, 2OII). For example, a study by Johns determined that the income of the Monroe County from the artificial reef was 32 million dollars, opening 2.300 new jobs. According to the study, there is great interest in the artificial reefs along the coast of Florida. The study estimates that the annual expense of artificial reef maintenance amounts to 9.4 million dollars, while the use value (the amount of money that the divers are ready to pay for the maintenance of the artificial reefs, as well as the construction of new ones) is 2.I million dollars. As an example of the positive socio-economic effects of the artificial reefs, we will examine the study of sunken warships in the Florida Keys coral archipelago, in USA. 
Socio-economic studies have shown that the sunken warships, U.S.S. Vandenberg and U.S.S. Spiegel Grove contribute to the development of the local economy through wreck diving. The study shows that after the sinking of U.S.S. Spiegel Grove in June 2002. scuba-diving on natural coral reefs has decreased while diving on artificial reefs has increased. The local economy also recorded an increase in cash inflow (US Department of Commerce, 2OI2; Leeworthy, et al., 2006). The study also shows that the annual worker wage has increased by a total of 96I.800 dollars, and that there were 70 new job openings. The study related to U.S.S. Vandenberg shows similar results. The U.S.S. Vandenberg, missile range instrumentation ship, was sunken in the water of Florida Keys, in May 2009. Following the deployment of the U.S.S. Vandenberg the net changes in the total recreational expenditures from the preto post-deployment period indicated that there was an increase of 6.5 million dollars in total recreational expenditures, which generated a total impact on sales of 7.29 million dollars, about 3.2 million dollars in income, and the creation of IO5 new jobs. After the sinking of aforementioned ships, the scuba-diving centers in Florida Keys recorded a I88.9\% business increase, or 49.000 more clients. Both studies aimed to show that the sinking of ships to reefs can be successfully promoted, thereby contributing to growth and development of the local economy and tourism (US Department of Commerce, 2OI2). In Australia, scuba-diving tourism industry is of great importance, and it is estimated to bring in about I billion Australian dollars in revenue (Edney, 2006; Harriott, 2002). Ship wreck SS Yongala, rests near the Great Barrier Reef in Queensland, and is officially one of the best artificial reefs in the world. The scuba-diving tourism industry plays a major role in the local economy (Edney, 2006; Cuthill, 1998). It is estimated that Yongala brings in I million Australian dollars annually from organized visits, not counting the profits from scuba-gear rental centers, airlines, accommodation services and restaurants (Edney, 2006; Delgado, 1998). The significance of scuba-diving tourism industry is acknowledged by the government as well. An example of this is the ship Brisbane, retired and sunken on the 3Ist of July 2005. near Sunshine Coast, for the purpose of creating a new attractive scuba-diving destination. It is estimated that the new destination will attract about $\mathbf{2 5}$.000 additional divers annually, increase scuba-diving

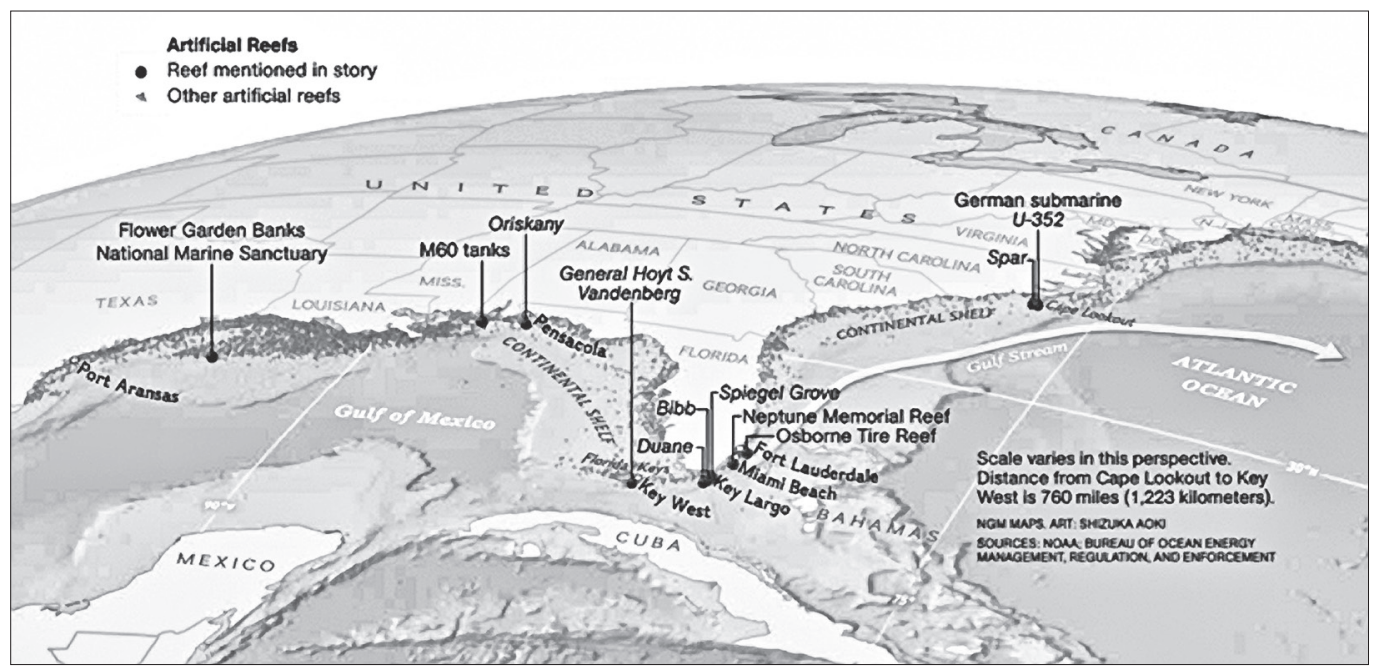

Figure 3. Location of mentioned ship wrecks

Source: http://www.reefball.org/album/==\%29\%20Non-Geographic\%20defined\%20Photos/graphics/slides/evolutionofartificialreefs.html 
activity in the region by $5 \%$, generate about I million Australian dollars in revenue and create about 200 new job openings (Environment Protection Agency, 2005). Ship wrecks in Chuuck Lagoon, within the Federal States of Micronesia, are one of the best artificial reefs in the world, and are promoted as scuba-diving destinations. These ship wrecks are the main tourist attractions of the Chuuk State, as well as the main source of income for the local economy. It is assessed that the high value of these wrecks comes from the possibility to see the contents of the ships, such as vehicles, tanks, ammunition and aircraft. The ship wrecks are very popular among divers, and also very beneficial to the local economy. The sustainable use of these assets is necessary not just because of the cultural value of the ships, but also because of the tourism industry and local communities that depend on the income from these assets.

\section{Research results}

The questionnaire consists of two parts. The first part is related to the attitude of the divers towards artificial reefs and wreck diving, while the second part is related to the socio-demographic characteristics of respondents. The first part is divided into 4 categories with the following themes: how many times did they participate in wreck diving, at which destinations, general attitude towards scuba-diving (motivation for scuba-diving and the reasons for not going scuba-diving), while the fourth category explores their experience with wreck diving and how artificial reefs affect the surrounding environment. In the second part of the questionnaire, the questions are related to gender, age, education and employment status. After the questionnaires were filled in, we proceeded to process the data.

Concerning the experience of the divers, $33 \%$ of the respondents claimed that they went wreck diving more than 40 times, while $56 \%$ went wreck diving up to 20 times (of which $28 \%$ went wreck diving up to 5 times). Most of them were diving in Egypt, Montenegro and Turkey, but other destinations like Aegean Sea, Bermuda, Thailand, North America, Russia and Micronesia are also present. $25 \%$ of the respondents fully agreed that they dive for the sake of exploration, while II\% dive professionally. Most of the respondents agreed that that they participate in scuba-diving because of adventure and beauty of the destination, with relaxation and escape from everyday life being the second most popular motive.

From the total number of respondents, $78 \%$ thinks that artificial reefs are attractive and interesting. Also $78 \%$ of them think that artificial reefs contribute to the affirmation of the destination as a wreck diving destination, and that they give the destination a good image. $69 \%$ of the respondents fully agreed that artificial reefs positively affect marine life, while $6 \%$ of them fully disagreed with this statement. It is a solid fact that artificial reefs attract a large number of divers and most of the respondents partially of fully agreed that they contribute to faster construction of scuba-diving centers. When the effects of artificial reefs on marine life are concerned, the questionnaire affirmed that the effects are strictly positive. 7I\% of the respondents fully agreed that artificial reefs contribute to preservation of endangered species and habitats, as well as that they can increase their productivity. When scuba-diving is concerned, it can be argued that the effects of the activity are mostly neutral, but can potentially be both positive and negative. To elaborate: the scuba-diving activity itself does not directly affect marine life on the artificial reef, but we can argue that there are both beneficial and harmful types of scuba-diving activities. Scuba-diving with the aim of monitoring the development of the artificial reef is certainly beneficial, while unprofessional behavior such as collecting artifacts as souvenirs is an example of the later. Although $94 \%$ of the respondents 
fully agreed that breaking off parts of the reef to keep as souvenirs and damaging the reef is not acceptable, $6 \%$ of them still answered that they mostly disagree. This raises the question whether all of the divers are acting professionally while underwater. On the question whether wreck diving negatively affects marine life, $66 \%$ of the respondents agreed that it does not, I7\% did not have an opinion on it, while II\% mostly agreed that it does.

\section{Discussion and conclusion}

Based on the aforementioned facts and the results of the questionnaire, it can be argued that most of the opinions concur when positive and negative effects of wreck diving on aquaculture and the scuba-diving tourism destination are concerned. The question we need to ask now is: how much does human activity actually affect such sites? Regardless of whether the scuba-diving tourism destination had previously developed mass tourism, where organized groups of divers would visit the destination, or adventure/exploration tourism with smaller groups, both types can have negative effects on the destination, not just seasonal ones, but long-term consequences that the local community would later have to deal with. The protection of marine life is foremost. The wrecks should be cleansed of toxic materials before they are submerged. Otherwise the toxic materials can cause bioaccumulation (accumulation of toxic materials in the tissue of living organisms). The secondary stage is bio magnification, which develops after bioaccumulation passes through the food chain cycle. However, if the cleansing is performed properly, these effects can be avoided. After submerging the structure, we can plan the development of tourism and adequate marketing, while making sure that we incorporate the principles of sustainable development. The development of tourism brings about rapid construction of tourism facilities. Because of this, the development should be planned according to previously determined parameters like carrying capacity, tourism zoning, effects on the environment and ethical codes. An example of negative effects of scuba-diving is anchoring, which can damage or even destroy a natural coral reef. Scuba-diving provides an opportunity for exploration, learning and enjoying the marine environment, and so the protection of that environment should be the responsibility of every diver. To avoid the possible negative effects, divers must be able to move skillfully underwater, and act professionally by: avoiding any contact of the flippers with the reef, avoiding contact of photography equipment with the reef, avoiding leaning onto any marine organism, and even slight touching is discouraged.

To conclude, it is not up to debate whether artificial reefs positively affect marine life, but rather are the people willing to preserve biodiversity of both marine and terrestrial ecosystems. Tourism itself is not necessarily hazardous for the environment, but there are many people that approach it irresponsibly, accounting only for short term effects, while failing to account for the long term ones as well as the possible consequences.

\section{References}

Anderson, R. (1997). Wrecks on the reef: A guide to the historic shipwrecks at Port Phillip Heads. Heritage Council of Victoria, Melbourne, Victoria.

Baine, M. (2OOI). Artificial reefs: a review of their design, application, management and performance. Ocean and Coastal Management 44, 24I-59. 
Barker, N. H. L., Roberts, C. M. (2004). Scuba diver behaviour and the management of diving impacts on coral reefs. Biological Conservation, I2O(4), 48I-489.

Bombace, G., Fabi, G., Fiorentini, L. (1993). Census results on artificial reefs in the Mediterranean Sea. Bollettino di Oceanologia Teorica ed Applicata II, 257-263.

Branden, K. L., Pollard, D. A., Reimers, H. A. (I994). A review of recent artificial reef developments in Australia. Bulletin of Marine Science 55(2-3), 982-994.

Brown, B. E. (I988). World-wide death of corals: natural cyclic events or man made pollution? Marine Pollution Bulletin I8, 9-I3.

Charbonnel, E. (2OO2). Effects of increased habitat complexity on fish assemblages associated with large artificial reef units (French Mediterranean coast). ICES Journal of Marine Science, 59, 208-2I3.

Cuthill, M. (1998). Managing the Yongala historic shipwreck. Coastal Management 26, 33-46.

Davis, D., Tisdell, C. (I996). Economic Management of Recreational Scuba Diving and the Environment. Journal of environmental management, (February I994), 229-248.

Delgado, J. P. (1988). The value of shipwrecks. in J Waldron Murphy (ed.), Historic shipwrecks: Issues in management. Partners for Livable Places and the National Trust for Historic Preservation, Washington DC. Pp. I-IO.

Department of Commerce (2OI2). Science review of Artificial Reefs. Web reference: http:// sanctuaries.noaa.gov.

Department of Planning. (I989). SS Duckenfield (I875 - I889): A case for declaration as an historic shipwreck. Heritage Branch, Department of Planning, Sydney, NSW.

Edney, J. (2006). Impacts of recreational scuba diving on shipwrecks in Australia and the Pacific: A review. Micronesian Journal of the Humanities and Social Sciences 5, 2OI-233.

Environment Protection Agency. (2005). Public benefit test for a proposed conservation park for the ex-HMAS Brisbane. Environment Protection Agency, Queensland Government, Brisbane, Queensland.

Fadli, N., Campbell, S. J., Ferguson, K., Keyse, J., Rudi, E., Riedel, A., Baird, A. H. (2OI2). The role of habitat creation in coral reef conservation: a case study from Aceh, Indonesia. Oryx, 46(O4), 5OI-507.

Feary, D. A., Burt, J. A., Bartholomew, A. (2OII). Artificial marine habitats in the Arabian Gulf: Review of current use, benefits and management implications. Ocean \& Coastal Management, 54(IO), 742-749.

Garrod, B., Gossling, S. (2008). Introduction. In: Garrod, B., Gossling, S. (Eds.), New Frontiers in Marine Tourism. Elsevier, Amsterdam, The Netherlands, pp. 3-28.

Gladstone, W., Curley, B., Shokri, M. R. (2OI3). Environmental impacts of tourism on the Gulf and Red Sea. Marine Pollution Bulletin 72, 375-388.

Hall, C.M. (2OOI). Trends in ocean and coastal tourism: the end of the last frontier? Ocean and Coastal Management 44, 60I-6I8.

Orams, M.B. (2007). Extreme marines: the rise of high risk marine tourism. In: Lück, M., Gräupl, A., Auyong, J., Miller, M.L., Orams, M.B. (Eds.), Proceedings of the 5th International Coastal and Marine Tourism Congress. AUT University, Auckland,New Zealand, p. 658.

Harriott, V. J. (20O2). Marine tourism impacts and their management on the Great Barrier Reef, CRC Reef Research Centre Technical Report No. 46, CRC Reef Research Centre, Townsville, Queensland.

Harriott, V. J., Davis, D., Banks, S. A. (I997). Recreational diving and its impact in marine protected areas in Eastern Australia. Ambio 26(3), I73-I79. 
Hawkins, J. P., Roberts, M. R. (1993). Can Egypts coral reefs support ambitious plans for diving tourism? Proceedings of the 7th International Coral Reef Symposium Guam 2, IOO7-IOI3.

Hess, R., Rushworth, D., Hynes, M., Peters, J. (2OOI). Disposal Options for Ships. National Defense Research Institute RAND, 59-80.

Hsui, C.Y., Wang, C.C. (2OI3). Synergy between fractal dimension and lacunarity index in design of artificial habitat for alternative SCUBA diving site. Ecological Engineering 53, 6-I4.

Hutchings, P. A. (I994). The pacific reefs: a paradise lost. Special issue. Marine Pollution Bulletin 29, I-I4O.

www. http://inkchromatography.wordpress.com

Jameson, S.C., Ammar, M.S.A., Saadalla, E., Mostafa, H.M., Riegl, B., (I999). A coral damage index and its application to diving sites in the Egyptian Red Sea. Coral Reefs I8, 333339.

Jeffery, B. (I993). Maritime archaeology: what's in it for Australian's?. Bulletin of the Australian Institute for Maritime Archaeology I7(2), I-6.

Jensen, A. C. (1997). European Artificial Reef Research. Proceedings of the first EARRN conference, March 1996 Ancona, Italy. Southampton Oceanography Centre, Southampton.

Jenson A. (1998). Final report of the European artificial reef research network. European Artificial reef research network. Web reference: /http://www.icit.hw.ac.uk/Finalreport. $\mathrm{rtf}$

Jewell, B. (2004). The effectiveness of interpretation on diver attitudes and awareness of underwater shipwreck values - SS Yongala, a case study. Bulletin of the Australasian Institute for Maritime Archaeology 28, 43-62.

Leeworthy, V.R., Maher, T., Stone, E. A. (2006). Can artificial reefs alter user pressure on adjacent natural reefs? Bulletin of Marine Science 78(I), 29-37.

Lindemann, K. (I992). Hailstorm over Truk Lagoon. Pacific Press Publications, Belleville, Michigan.

Nichols R. S. (2OI3). Effectiveness of artificial reefs as alternative dive sites to reduce diving pressure on natural coral reefs, a case study of Koh Tao, Thailand, University of Cumbria.

Nutley, D. (1996). Issues in management archaeology. Tempus Archaeology and Material Culture Studies in Anthropology 5, 99-IO5.

Pendleton, L. H. (2005). Understanding the Potential Economic Impacts of Sinking Ships for SCUBA Recreation. Marine Technology Society Journal 39, 47-52.

Pickering, H., Whitmarsh, D., Jensen, A. (I998). Artificial Reefs as a Tool to Aid Rehabilitation of Coastal Ecosystems: Investigating the Potential. Marine Pollution Bulletin 37, 505$5 \mathrm{I} 4$.

Rilov, G., Benayahub, Y. (I998). Vertical Artificial Structures as an Alternative Habitat for Coral Reef Fishes in Disturbed Environments. Marine environmental research, 45, 43I-5I.

Rilov, Gil., Benayahu, Y. (2OO2). Rehabilitation of coral reef-fish communities: the importance of artificial-reef relief to recruitment rates. Bulletin of marine Science, 7O(I), I85-I97.

Salvat, B. (1987). Human impacts on coral reefs: Facts and recommendation. Antenne Museum Ecole Pratique des Hautes Etudes, French Polynesia, p. 253. San Diego.

Sayer, M.D.J, Wilding T.A. (20O2). Planning, licensing, and stakeholder consultation in an artificial reef development: the Loch Linnhe reef, a case study. ICES Journal of Marine Science $59, \mathrm{I} 78-85$. 
Stanley, D. R., Wilson, C. A. (1990). A fishery dependant based study of fish species composition and associated catch rates around oil and gas structures of Louisiana. Fisheries Bulletin 88, 7I9-73O.

Stone, R. B., McGurrin, J. M., Sprague, L. M., Seaman, W. Jr. (I99I). Artificial habitats of the world: synopsis and major trends. In Artificial Habitats for Marine and Freshwater Fisheries, eds. W. Seaman, Jr. and L. M. Sprague, pp 3I-60. Academic Press.

Sutton, G. S., Bushnell, S. L. (2007). Socio-economic aspects of artificial reefs: Consideration for the Great Barrier Reef Marine Park. Ocean and Coastal Management 5O, 829-846.

Tratalos, J.A., Austin, T.J., (2OOI). Impacts of recreational SCUBA diving on coral communities of the Caribbean island of Grand Cayman. Biological Conservation IO2, 67-75.

Treeck, V. P., Schuhmacher, H. (I998). Mass Diving Tourism - A New Dimension Calls for New Management Approaches. Marine Pollution Bulletin 37, 499-5O4.

UNEP (United Nations Environment Programme), (2009). Sustainable Coastal Tourism An Integrated Planning Management Approach, p. 87.

UNWTO, 2OI2a. International Tourism to Reach one Billion in 2OI2. <http://media.unwto. $\mathrm{org} / \mathrm{en} / \mathrm{press}$-release/2OI2-OI-I6/international-tourism-reach-one-billion-2OI2>.

Uy, F. A, Caindec, V. E. C., Perez, J. L. D., Dy, D. T. (2008). Impacts of recreational scuba diving on a marine protected area in central Philippines: A case of the Gilutongan marine sanctuary. The Philippine Scientist, 42(I7), I44-I58.

Wilkinson, C. R. (I993). Coral reefs of the world are facing widespread devastation: can we prevent this through sustainable management practice. Proceedings of the 7 th International Coral Reef Symposium Guam I, II-2I.

Wilson, C. A., Van Sickle, V. R. (1987). Development of the Louisiana artificial reef programme. Bulletin of Marine Science 44(2), IO7I-IO72.

Wood, P. (2OIO). A Conceptional Exploration of Marine Research Tourism in Australia: A Study of the Conceptual, Supply and Demand Nature of Marine Research Tourism in Australia, School of Business. James Cook University, Australia, p. 805. <http://eprints. jcu.edu.au/I0934>.

Zakai, D., Chadwick-Furman, N.E. (20O2). Impacts of intensive recreational diving on reef corals at Eilat, northern Red Sea. Biological Conservation I05, I79-I87.

www.bsac.com/default.asp

www.coral.org

www.inkchromatography.files.wordpress.com

www.reefball.org 